\title{
The Effect of Complex Instruction Team Product (CITP) Learning Model on Increase Student's Skills
}

\author{
Dominggus Rumahlatu \\ Pattimura University, Indonesia, dominggus_amq@yahoo.co.id \\ Kristin Sangur \\ Pattimura University, Indonesia, sangur_kristin@yahoo.com
}

\section{Sintje Liline}

Pattimura University, Indonesia, sinline28@yahoo.com with Team Product (CITP) learning model on students' creative thinking skills, critical thinking skills, metacognitive skills, scientific attitudes, cognitive learning results, and retention. This research used quasi-experimental design with pretestposttest nonequivalent control group design. This research was carried out in several Senior High Schools in Ambon, namely SMA 1 Ambon, SMA 4 Ambon, SMA 5 Ambon, SMA 13 Ambon, and SMA Kristen Ambon in the even semester of the academic year 2017/2018. The results of the research were analyzed using ANCOVA. A post hoc LSD test was also performed if there were differences in each variable. The results of the research show that the CITP learning model affects creative thinking skills, critical thinking skills, metacognitive skills, scientific attitudes, cognitive learning results, and retention of class X senior high school students on Ecosystem learning material. The syntax of the CITP learning model can improve students' creative thinking skills, critical thinking skills, metacognitive skills, scientific attitudes, cognitive learning results, and retention compared to the learning model commonly implemented by the biology teachers.

Keywords: CITP, creative thinking skills, critical thinking skills, cognitive learning results, metacognitive skills, retention and scientific attitudes

\section{INTRODUCTION}

Education in Indonesia continues to develop following the changes in the world, namely the fourth industrial revolution era (IR 4.0). The Ministry of Research, Technology and Higher Education of Republic of Indonesia (RISTEKDIKTI - RI) states that the challenges of IR 4.0 must be immediately and appropriately responded by all stakeholders in the Ministry of Research, Technology and Higher Education 
(Kemenristekdikti) in order to improve the competitiveness of Indonesia in the middle of global competition (Kementerian Riset, Teknologi, dan Pendidikan Tinggi Republik Indonesia, 2018). Therefore, education in Indonesia should prepare students to become human resources capable of competing in the current era of IR 4.0.

The World Economic Forum reports that Indonesia is one of the high potential countries towards IR 4.0 (Dimyati, 2018). Therefore, education in Indonesia must be able to prepare students to be able to compete and survive in the IR 4.0 era. In order to be able to survive, students need to be equipped with several skills and abilities, such as creative thinking skills, critical thinking skills, metacognitive skills, cognitive ability, scientific attitudes, and retention. Erol, Jager, Hold, Ott, \& Sihn (2016) explain that the competencies needed in the working world are personal competence, interpersonal competence, competencies related to actions, competencies related to domains that include methodology and language. Developing critical thinking skills, creative thinking skills, cognitive skills, retention, and metacognitive skills are classified as developing personal competencies while developing scientific attitudes is part of developing interpersonal competence. The World Economic Forum also defines the skills that must be possessed by the human resources in the future are Cognitive Abilities, System Skills, Complex Problem Solving, Content Skills, and Process Skills (Dimyati, 2018). Therefore, improving the quality of biology learning is a challenge for biology teachers nowadays.

In the learning process, the teachers are responsible for preparing students to be able to compete in the working world. The development of students' creative skills is essentially required because these skills are what the entrepreneurs today need (Ramankulova, Usembayeva, Berdia, Omarova, Baimukhanbetova, \& Shektibayeva, 2016). This is because creative skills enable students to solve problems creatively (Mumford, Medeirod, \& Partlow, 2012). According to Kopzhassarova, Akbayeva, Eskazinove, Belgibayeva, \& Tazhikeyeva (2016), critical thinking is the ability to find and determine objective ways of receiving information, comparing and analyzing various perspectives, understanding complexity and appreciating differences in answers. Mite \& Corebima (2017) state that critical thinking is one of the skills needed in this century to prepare students for education and work life. Saglam, Cankaya, Ucer, \& Cetin (2017) add that critical thinking skills are high order thinking skills that are obtained after mastering the low order thinking skills.

To empower the students' critical and creative thinking skills, teachers need to consider the students' metacognitive abilities. According to Al-Khayat (2012), metacognition is the ability to realize, pay attention to, and use information about personal cognitive processes, so that one can effectively improve his performance on cognitive tasks. Based on the definition above, the metacognitive abilities are also needed in learning to improve students' critical and creative thinking skills. Metacognitive skills have been proven to empower students' critical thinking skills at the implementation of problembased learning model (Buku, Corebima, \& Rohman, 2016; Rumahlatu \& Sangur, 2017), improve students' creative thinking skills (Yusnaeni, Corebima, Susilo, \& Zubaedah, 2017), and improve student self-efficacy (Rahimirad \& Zare-ee, 2015). Self-efficacy function as confidence so that it gives influence to the way of thinking, affection, self- 
motivation, and well-behave in accomplishing all learning tasks (Sharma \& Nasa, 2014). Zimmerman (2000) adds that one of the closest constructs for self-efficacy is selfconcept. This means that self-efficacy is one part of the scientific attitudes. Therefore, by developing students' scientific attitudes, it is expected that students can think, motivate themselves and behave during the learning process. This can improve students' cognitive learning results and students' retention. Jahangard, Jahan, Soltani, \& Alinejad (2016) add that metacognitive skills are related to the construct of meta processes and metamemory. In addition, metacognition is related to understanding and monitoring cognition (Lai, 2011). Metacognitive skills are also defined as the awareness of cognitive processes, and subcomponents of cognitive thinking which are declarative, procedural, and knowledge (Stephanou \& Mpiontini, 2017).

The challenges that the teachers face in the era of IR 4.0 are to change the learning paradigm and to improve the students' low order thinking skills into higher-order thinking skills, as well as to improve and to make students accustomed to scientific attitudes. The educational challenges in the era of IR 4.0 are to change students' learning methods, thinking patterns, mindset, and ways of acting in developing creative innovations in various fields, so as to reduce unemployment in Indonesia, especially in global market competition. To face the educational challenges of IR 4.0, teachers need to prepare their competencies, professionalism and the quality of learning (Riyana, 2018).

One of the things related to the quality of learning is integrating learning models and learning methods to produce innovation in learning. The Complex Instruction and Team Product (CITP) learning model are one of the learning models that can be integrated to produce a combination of innovative learning syntax. This learning model is originated from the complex instruction learning model and the team product learning method. It should be known that the learning model will be well implemented if it is supported by suitable learning methods. Several types of research have been conducted on the combination of learning models, and the results of the research show a significant effect. Kristiani, Susilo, Rohman, \& Corebima (2015) report that through the implementation of the TEQI learning model (Thinking Empowerment through Questioning (TEQ) integrated with Inquiry learning), metacognitive skills and scientific attitudes have a positive contribution toward the students' academic achievement. In addition, a combination of the JIGSAW learning model and Discovery learning by Chomsiati \& Baskoro (2014) found that the development of SAVE learning model in the digestive system learning material, and the results of the research are feasible to support the learning in the learning material and could improve students' learning results and social interaction.

Therefore, the combination of the CITP learning model is expected to have a significant contribution toward the creative thinking skills, critical thinking skills, metacognitive skills, scientific attitudes, cognitive learning results, and retention of class $\mathrm{X}$ senior high school students in Ambon. The combination of the CITP learning model is to complement the weaknesses of the Complex Instruction learning model and the Team Product learning method. Huda (2013) states that the Complex instruction learning model emphasizes on discovery-based projects that are limited to writing, while the 
Team Product learning method emphasizes on cooperative activities that produce a product, but it has a short learning syntax. Based on these strengths and weaknesses, the combination of CITP is a solution to provide the students with the discovery/investigation-based learning experiences and to produce products that can be presented in front of the class. Therefore, this research is essential to be conducted to investigate the effect of the combination of the CITP learning model on creative thinking skills, critical thinking skills, metacognitive skills, scientific attitudes, and learning outcomes of class X students in several senior high schools in Ambon.

\section{METHOD}

\section{Research Design}

This quasi-experimental research was conducted to compare the effectiveness of conventional learning models and the combination of CITP learning models on students' creative thinking skills, critical thinking skills, metacognitive skills, scientific attitudes, cognitive learning results, and retention. The design of this research (Table 1) was the pretest-posttest nonequivalent control group design (Borg \& Gall, 1983).

Table 1

Pretest-Posttest Nonequivalent Control Group Design

\begin{tabular}{lll}
\hline Pretest & Treatment & Posttest \\
\hline $\mathrm{O}_{1}$ & $\mathrm{X}_{1}$ & $\mathrm{O}_{2}$ \\
$\mathrm{O}_{3}$ & $\mathrm{X}_{2}$ & $\mathrm{O}_{4}$ \\
\hline Description: & & \\
$\mathrm{O}_{1}$ and $\mathrm{O}_{3}$ & : Pretests \\
$\mathrm{O}_{2}$ and $\mathrm{O}_{4}$ & : Posttests \\
$\mathrm{X}_{1}$ & : Conventional learning model \\
$\mathrm{X}_{2}$ & : CITP learning model
\end{tabular}

\section{Study Sample}

The research was conducted at five Senior High Schools (SMA) in Ambon City, Indonesia namely SMA 1 Ambon, SMA 4 Ambon, SMA 5 Ambon, SMA 13 Ambon, and SMA Kristen Ambon. The determination of schools as research samples uses a purposive sampling technique that is based on the condition that there were only five schools available that could be used as data collection locations. The sample of this research was the students majoring in science programs during the even semester of the 2017/2018 academic year with a total sample of 321 students. This research used two classes of class X science from each school. The classes used in this research were determined by using a simple random sampling technique by using a lottery. The samples of this research were the students with homogeneous academic abilities.

\section{Research Instruments}

The research data were collected by using test and non-test techniques. The test instrument was used to measure the students' cognitive learning results on the Ecosystem learning material. The test instrument was in the form of an essay test, which had been validated by education experts and had been tested for its reliability. The results of the reliability analysis of the question instruments were obtained from the Cronbach's Alpha value $(\alpha=0.925)$, which means that the question instruments were very good (Excellent). The essay test was given before (pretest) and after (posttest) the 
learning process by using the combination of the CITP learning model. The non-test instrument used in this research was in the form of observation sheets to reveal to students' scientific attitudes. The observation sheet was developed by the researchers by following the indicators of scientific attitudes, which included curiosity, critical, diligence, creativity, honesty, openness, and collaboration (Kristiani et al., 2015; Candrasekaran, 2014). The students' creative thinking skills were measured by using an essay test based on five aspects of creative thinking, namely fluency, flexibility, originality, elaboration, and assessment (Treffinger, Young, Selby, \& Shepardson, 2002). The students' critical thinking skills as measured by using an essay test based on a modified critical thinking rubric (Zubaidah, Corebima, \& Mistianah, 2015) which consisted of five components (scores) of critical thinking. The students' metacognitive skills were measured by using an essay test based on metacognitive skills rubric developed by Corebima (2009) which consisted of seven components (scores). Retention was measured with essay questions and the assessment used cognitive learning outcomes rubric.

\section{Research Processes}

Two classes from each school were taught by using different learning models namely conventional learning in the control class and the combination of the CITP learning model in the experimental class. The concept of the learning material taught in all research classes was about the concept of the ecosystem. The control class was taught by using the learning model and method commonly used by the teacher such as Think Pair and Share (TPS), Number Heads Together (NHT) and Student Team Achievement Division (STAD) and Observation. While the experimental class was taught by using the combination of CITP learning model with the syntax (learning phases) as follows: (1) the teacher prepares the learning material; (2) the teacher prepares a role card (facilitator, note-taker, recorder) for students, (3) the teacher divides students in groups, (4) the teacher asks the students to take role cards randomly and attach them on their own chest, (5) the teacher briefly presents the learning material, (6) the teacher instructs students to choose ideas according to the learning material taught, (7) students collect information, (8) teachers instruct students to solve problems through discovery/Investigation, (9) the students make creative work, (10) the teacher instructs the students to present the results of their work in front of the class. The assessment of scientific attitudes is carried out during the learning process, i.e. at the beginning and end of learning used observation sheets, while the assessment of creative thinking skills, critical, metacognitive, and student learning outcomes was done at the beginning and end of learning used essay test questions. Meanwhile, the assessment of retention was carried out after two weeks of the learning process also used the essay test questions.

\section{Data Analysis}

The data were analyzed by using the ANCOVA test and then followed with the post hoc LSD test (the Smallest Significant Difference test). The results of the pretest on creative thinking skills, critical thinking skills, metacognitive skills, scientific attitudes, cognitive learning results, and posttest were used as the covariates. Before the ANCOVA test was performed, the normality and the homogeneity of the data were tested by using the Kolmogorov-Smirnov test and Levene's test. 


\section{FINDINGS}

The results of the ANCOVA test on students' creative thinking skills are presented in Table 2. The results of the ANCOVA test on students' critical thinking skills are presented in Table 4. The results of the ANCOVA test on students' metacognitive skills are presented in Table 6. The results of the ANCOVA test on students' scientific attitudes are presented in Table 8. The results of the ANCOVA test on students' cognitive learning results are presented in Table 10. The results of the ANCOVA test on students' retention are presented in Table 12.

Table 2

The Results of ANCOVA Test on Students' Creative Thinking Skills

\begin{tabular}{llllll}
\hline Source & Type III Sum of Squares & df & Mean Square & F & Sig. \\
\hline Corrected Model & 7581.624 & 2 & 3790.812 & 239.172 & .000 \\
Intercept & 19231.422 & 1 & 19231.422 & 1213.358 & .000 \\
Initial,_Creative,_Thinking,_Skills & 20.327 & 1 & 20.327 & 1.282 & .258 \\
Learning Model & 7570.213 & 1 & 7570.213 & 477.623 & .000 \\
Error & 5024.373 & 317 & 15.850 & & \\
Total & 89517.000 & 320 & & & \\
Corrected Total & 12605.997 & 319 & & & \\
\hline
\end{tabular}

Table 2 shows that the learning model affects students' creative thinking skills ( $\mathrm{p}<$ sig. 05). Moreover, the results of the post hoc test on students' creative thinking skills are presented in Table 3.

Table 3

Test Results of LSD Test on Students' Creative Thinking Skills

\begin{tabular}{lll}
\hline Learning Model & Mean & Notation \\
\hline CITP Learning Model & 20.491 & a \\
Conventional Learning Model & 10.759 & a \\
\hline
\end{tabular}

Table 3 shows that the notation of the CITP learning model and the conventional learning model is the same in improving students' creative thinking skills, but the mean score shows a difference of 9.73 points.

Table 4

The Results of ANCOVA Test on Students' Critical Thinking Skills

\begin{tabular}{llllll}
\hline Source & Type III Sum of Squares & df & Mean Square & F & Sig. \\
\hline Corrected Model & 20381.497 & 2 & 10190.749 & 161.018 & .000 \\
Intercept & 42728.616 & 1 & 42728.616 & 675.129 & .000 \\
Initial_Critical_Thinking_Skills & 81.267 & 1 & 81.267 & 1.284 & .258 \\
Learninng_Model & 20306.962 & 1 & 20306.962 & 320.858 & .000 \\
Error & 19809.626 & 317 & 63.290 & & \\
Total & 205749.000 & 320 & & & \\
Corrected Total & 40191.123 & 319 & & & \\
\hline
\end{tabular}


Table 4 shows that the learning model affects students' critical thinking skills ( $\mathrm{p}<$ sig. 0.05). While the results of the post hoc test on the students critical thinking skills are presented in Table 5.

Table 5

The Results of LSD Test on Students' Critical Thinking Skills

\begin{tabular}{ccc}
\hline Learning Model & Mean & Notation \\
\hline CITP Learning Model & 31.008 & a \\
Conventional Learning Model & 14.974 & a \\
\hline
\end{tabular}

Table 5 shows that the notation of the CITP learning model and the conventional learning model is the same in improving students' critical thinking skills, but the mean score shows a difference of 16.03 points.

Table 6

The Results of ANCOVA Test on Students' Metacognitive Skills

\begin{tabular}{llllll}
\hline Source & Type III Sum of Squares & df & Mean Square & F & Sig. \\
\hline Corrected Model & 34826.326 & 2 & 17413.163 & 165.126 & .000 \\
Intercept & 115199.764 & 1 & 115199.764 & 1092.422 & .000 \\
Initial_Metacognitive_Skills & 114.346 & 1 & 114.346 & 1.084 & .299 \\
Learninng_Model & 34522.234 & 1 & 34522.234 & 327.369 & .000 \\
Error & 33428.770 & 317 & 105.454 & & \\
Total & 385271.296 & 320 & & & \\
Corrected Total & 68255.096 & 319 & & & \\
\hline
\end{tabular}

Table 6 shows that the learning model affects students' metacognitive skills ( $\mathrm{p}<$ sig. 0.05). While the results of the post hoc test on the students' metacognitive skills are presented in Table 7.

Table 7

The Results of LSD Test on Students' Metacognitive Skills

\begin{tabular}{lcc}
\hline \multicolumn{1}{c}{ Learning Models } & Mean & Notation \\
\hline CITP Learning Model & 42.132 & a \\
\hline Conventional Learning Model & 21.338 & a \\
\hline
\end{tabular}

Table 7 shows that the notation of the CITP learning model and the conventional learning model is the same in improving students' metacognitive skills, but the mean score shows a difference of 20.79 points.

Table 8

The Results of ANCOVA Test on Students' Scientific Attitudes

\begin{tabular}{llllll}
\hline Source & Type III Sum of Squares & df & Mean Square & F & Sig. \\
\hline Corrected Model & 17069.491 & 1 & 17069.491 & 3578.1369 & .000 \\
Intercept & .000 & 0 &. &. &. \\
Initial_Scientific_Attitudes & .000 & 0 & 20.479 & .439 & .510 \\
Learninng_Model & 17069.491 & 1 & 17069.491 & 3578.1369 & .000 \\
Error & 1497.936 & 317 & 4.770 & & \\
Total & 136591.000 & 320 & & & \\
Corrected Total & 18567.427 & 319 & & & \\
\hline
\end{tabular}


Table 8 shows that the learning model affects students' scientific attitude ( $\mathrm{p}<$ sig.0.05). While the results of the post hoc test on the students's cientific attitudes are presented in Table 9.

Table 9

The Results of LSD Test on Students' Scientific Attitudes

\begin{tabular}{lll}
\hline Learning Model & Mean & Notation \\
\hline CITP Learning Model & 26.769 & $\mathrm{a}$ \\
Conventional Learning Model & 12.069 & $\mathrm{a}$ \\
\hline
\end{tabular}

Table 9 shows that the notation of the CITP learning model and the conventional learning model is the same in improving the students' scientific attitudes, but the mean score shows a difference of 14.7 points.

Table 10

The Results of ANCOVA Test on Students' Cognitive Learning Results

\begin{tabular}{llllll}
\hline Source & Type III Sum of Squares & df & Mean Square & F & Sig. \\
\hline Corrected Model & 37094.863 & 2 & 18547.431 & 137.690 & .000 \\
Intercept & 116417.608 & 1 & 116417.608 & 864.244 & .000 \\
Initial_Cogntive_Learning_Results & 408.379 & 1 & 408.379 & 3.032 & .083 \\
Learninng_Model & 37007.707 & 1 & 37007.707 & 274.733 & .000 \\
Error & 42701.325 & 317 & 134.704 & & \\
Total & 431584.000 & 320 & & & \\
Corrected Total & 79796.187 & 319 & & & \\
\hline
\end{tabular}

Table 10 shows that the learning model affects students' cognitive learning results $(\mathrm{p}<$ sig. 0.05$)$. The results of the post hoc test on the students' cognitive learning results are presented in Table 11.

Table 11

The Results of LSD Test on the Students' Cognitive Learning Results

\begin{tabular}{lll}
\hline Learning Model & Mean & Notation \\
\hline CITP Learning Model & 44.200 & $\mathrm{a}$ \\
Conventional Learning Model & 22.651 & $\mathrm{a}$ \\
\hline
\end{tabular}

Table 11 shows that the notation of the CITP learning model and the conventional learning model is the same in improving students' cognitive learning results, but the mean score shows a difference of 21.55 points. 
Table 12

The Results of ANCOVA Test on Students' Retention

\begin{tabular}{llllll}
\hline Source & Type III Sum of Squares & df & Mean Square & F & Sig. \\
\hline Corrected Model & 92815.930 & 2 & 46407.965 & 440.803 & .000 \\
Intercept & 14036.174 & 1 & 14036.174 & 133.322 & .000 \\
Initial_Retention & 4421.221 & 1 & 4421.221 & 41.995 & .000 \\
Learninng_Model & 30082.873 & 1 & 30082.873 & 285.740 & .000 \\
Error & 33373.917 & 317 & 105.280 & & \\
Total & 423443.000 & 320 & & & \\
Corrected Total & 126189.847 & 319 & & & \\
\hline
\end{tabular}

Table 12 shows that the learning model affects students' retention ( $\mathrm{p}<$ sig. 0.05). While the results of the post hoc test on the students' retention are presented in Table 13.

Table 13

The Results of LSD Test on Students' Retention

\begin{tabular}{lll}
\hline Learning Model & Mean & Notation \\
\hline CITP Learning Model & 44.003 & $\mathrm{a}$ \\
\hline Conventional Learning Model & 17.613 & $\mathrm{a}$ \\
\hline
\end{tabular}

Table 13 shows that the notation of the CITP learning model and the conventional learning model is the same in improving students' retention, but the mean score shows a difference of 26.39 points.

\section{DISCUSSION}

\section{The Effect of Learning Models on Students' Creative Thinking}

The results of the statistical test using the ANCOVA technique (Table 2) show that the CITP learning model has an effect on students' creative thinking skills with a significant value of $<\alpha 0.05$. This shows that the learning model affects students' creative thinking skills in several senior high schools in Ambon.

The results of the LSD test show that the creative thinking skills of the students taught by using the combination of the CITP learning model and those taught by using the conventional learning model were not significantly different. However, the mean scores of the creative thinking skills of the students taught by using different learning models are also different (Table 3). Through the implementation of the CITP learning model, the students were able to develop their creative thinking skills, so that it was different from the students taught by using the conventional learning model.

The CITP learning model is one of the innovative learning models because it is the combination of the Complex Instruction learning model and the Team Product learning model. This combination of these learning models can optimize the students' potential in learning because it makes the students actively involved, both mentally and physically, in the learning process. This can be seen from the syntax of the CITP learning model 
which includes awareness towards roles within groups, gathering information, carrying out investigations, and producing creative products.

At the stage of the teacher instructing the students to choose ideas for investigation, it can encourage the students to think of finding creative ideas. The teacher can encourage students to come up with ideas and then find ways to conduct investigations to answer their ideas. The stage of ecosystem observation investigation in the environment to solve ideas also makes the students accustomed to thinking creatively. At this investigation stage, the students will try various ways to solve the creative ideas which they already find in the previous stage. This is in accordance with the opinion of Leen, Hong, Kwan, \& Ying (2014) that to solve problems, students need to use their creative thinking and critical thinking to choose the best strategies, to develop solutions, or to consider the consequences for each solution. On the other hand, Yusnaeni et al. (2017) explain that creative thinking skills will produce creative generations that have the potential to solve social problems and even complex environmental problems. Zubaidah, Fuad, Mahanal, \& Suarsini (2017) add that one way to develop students' creative thinking skills is to manage and to understand information. After completing the investigation stage, the students are assigned to produce creative works or products to be presented in front of the class. At this stage, students are also required to have the creativity to produce creative products.

Students' creative thinking can be trained when the students use their imagination, intelligence, insight, and ideas and when they cooperate with their peers (Birgili, 2015; Davies, Jindal-Snape, Collier, Digbya, Haya, \& Howea, 2013). In this case, the CITP learning model provides assignments and opportunities for each student to use their intelligence and creative ideas to complete the tasks given by the teacher. According to Treffinger et al. (2002), the students creative thinking skills is characterized by students' ability to produce a number of ideas (fluency), the ability to produce new ideas in different and varied ways (flexibility), the ability to produce new and unique ideas (originality), the ability to enrich ideas to be more interesting and more complex (elaboration), and the ability to use comparisons or analogies to make new connections (metaphorical thinking). Coffman (2013) argues that students' creative thinking skills can be trained using several ways, such as giving students questions and inviting students to actively participate in learning, exploring topics and learning materials using primary / real data, and thinking of new ways to communicate new findings. The implementation of traditional learning models and learning methods such as discovery, investigation, and observation have not been able to provide the opportunities for the students to use their creative thinking so that the potential of students' creative thinking has not been maximally developed. Sompong (2018) reports that to train students' creative thinking requires group work using project-based learning.

\section{The Effect of Learning Models on Students 'Critical Thinking Skills}

The results of the statistical test using the ANCOVA technique (Table 4) show that the combination of the CITP learning model has an effect on students' critical thinking skills with a significant value of $<\alpha 0.05$. This shows that the learning model affects students' critical thinking skills in several senior high schools in Ambon. 
The results of the LSD test show that the critical thinking skills of the students taught by using the CITP learning model were not significantly different from those of the students taught by using the conventional learning model. However, the mean scores of the critical thinking skills of the students taught by using the different learning models also show a difference (Table 5). The students taught by using the CITP learning model were able to develop their critical thinking skills so that it was different from the students taught by using the conventional learning model. The results of this research are in line with the research results by Bustami \& Corebima (2017) that the combination of the JiRQA learning strategy was able to develop students' critical thinking better than the conventional learning model.

The difference in the mean scores of the students' critical thinking skills is viewed from the syntax of the CITP learning model. One of the steps in the syntax of the CITP learning model is that the teacher instructs the students to choose ideas based on the learning material taught. At this step, the students are encouraged to think about ideas to complete the tasks given. Critical thinking involves the ability to observe a phenomenon, to give ideas to solve problems, to draw conclusions, and to evaluate the validity of statements, ideas, and arguments (Seferoglu \& Akbiyik, 2006; Howard, Tang, \& Austin, 2015). On the other hand, Zubaidah, Corebima, Mahanal, \& Mistianah (2018) state that critical thinking skills can be improved through the inquiry process in the GI learning model. This shows that the implementation of the CITP learning model can develop the inquiry process so that the students' critical thinking skills will also develop. In addition, Hasan, Tumbel, \& Corebima (2013) report that the combination of Student Team Achievement Divisions and Teams Games Tournaments (STAD + TGT) learning model can develop students' critical thinking skills.

The students do not automatically have critical thinking skills, therefore teacher needs to guide direct them. Because critical thinking does not appear automatically, at the stage of the combination of the two learning models the students are once again trained to develop their critical thinking skills. The next stage is to produce creative products based on the results of the investigation or observation according to the ideas that have been previously done. To produce creative ideas requires collaboration and discussion as well as various thoughts from the group members. Facione (2015) states that critical thinking is defined as interpretation, analysis, conclusion, evaluation, explanation until self-regulation. Therefore, through the activity of producing creative products, students can interpret and analyze the results of the investigation and then put them in the form of the creative product. Through the activities of analysis and interpretation, the students can hone their critical thinking skills. Furthermore, Kusuma, Gunarhadi, \& Riyadi (2018) states that interpretation is illustrating and giving reasons, while analysis is determining the relationship between partial understanding.

The students' critical thinking skills were not maximally honed in conventional learning in the control class. This is influenced by the learning model and learning method used by the teacher in teaching the concept of the ecosystem. The implementation of the combination learning model empowers students' critical thinking skills better. This is in line with Sele, Corebima, \& Indriwati (2016) that the implementation of the 
combination of Reciprocal Teaching and Think Pair and Share (RT + TPS) learning model had a better effect on students' critical thinking skills than the implementation of RT and TPS learning models separately.

\section{The Effect of Learning Model on Students' Metacognitive Skills}

The results of the statistical test using the ANCOVA technique (Table 6) show that the combination of the CITP learning model has an effect on students' metacognitive skills with a significant value of $<\alpha 0.05$. This shows that the learning model affects students' metacognitive skills in several senior high schools in Ambon.

The results of the LSD test show that the metacognitive skills of the students taught by using the combination of the CITP learning model were not significantly different from those taught by using the conventional learning model. However, the mean scores of the metacognitive skills of the students taught by using different learning models also show a difference (Table 7). Through the implementation of the combination of the CITP learning model, the students were able to develop their metacognitive skills, so that they were different from the students taught by using the conventional learning model.

The results of this research show that the students taught by using the combination of CITP learning models had better metacognitive skills than those taught by using the conventional learning model that was commonly implemented by the teachers. The conventional learning does not provide conditions for developing students' metacognitive skills. This is because the students tended to have a discussion based on the student worksheets (LKS) and then present the results of their discussion. The CITP learning model, however, can empower students' metacognitive skills.

This is because the stages of the CITP learning model familiarize the students with understanding the tasks given by the teacher, carry out an investigation plan, evaluate the actions taken during the investigation process. This opinion is supported by Kristiani et al. (2015) that the students need the metacognitive skills to understand the tasks given and develop strategies to complete the tasks. In the implementation of the CITP learning model, the teachers also teach students to formulate problems in the form of creative ideas, find solutions through investigation, and produce creative products. Listiana, Susilo, Suwono, \& Suarsini (2016) explain that the stages that can empower students' metacognitive skills include determining the topic of investigation, planning an investigation strategy, conducting an investigation, and presenting the results of the investigation. Also, Buku et al. (2016) argue that through metacognitive skills, students can monitor their thinking process, so that it leads towards the expected goal, increase their self-confidence, set a deadline for the completion of a task. Moreover, Mas'ud \& Arsyad (2018) adds that metacognitive skills are the knowledge that can help students solve problems or tasks.

The advantages of the combination of the CITP learning model are that it optimizes the empowerment of students' metacognitive skills, and both of the combined learning models complete each other's strengths and weaknesses. The results of this research are in line with several research results on the combinations of learning models, such as the researches conducted by Kristiani et al. (2015); Listiani et al. (2016); Umam, 
Suswandari, Asiah, Wibowo, \& Rohim (2018); Hariyadi, Corebima, Zubaidah, \& Ibrohim (2018).

\section{The Effect of Learning Models on Students' Scientific Attitudes}

The results of the statistical test using the ANCOVA technique (Table 8) show that the combination of CITP learning models has an effect on students' scientific attitudes with a significant value of $<\alpha 0.05$. This shows that the learning model affects the students' scientific attitudes in several senior high schools in Ambon.

The results of the LSD test show that the scientific attitudes of students taught by using the combination of the CITP learning model are not significantly different from those of the students taught by using the conventional learning model. However, the mean score of the scientific attitudes of the students taught by using different learning models also shows a difference (Table 9). Through the combination of CITP learning, the students were able to develop their scientific attitudes, so that it is different from the students taught by using the conventional learning model.

The scientific attitudes developed in the learning process using the combination of the CITP learning model are curiosity, critical, diligence, creativity, honesty, openness and cooperation. The research conducted by Kristiani et al. (2015) also observed students' scientific attitudes during the learning process, namely honesty, discipline, responsibility, environmental care, and cooperation. The syntax of the combination of the CITP learning model can develop students' scientific attitudes. The students' curiosity is developed during the idea selection stage. The students' critical attitude can be developed during the idea selection and information collection stages. Students can be critical of the information obtained. The students' determination can be honed during the learning process when students face challenges and difficulties. Similarly, Mukhopadhyay (2014) also states that scientific attitudes encourage questioning thoughts and improving the spirit of conducting an investigation. The students' creative attitudes can be developed during the stage of making creative works. The students' honesty can be developed during the investigation process and honestly present the product or results of their investigation.

The research by Balaji (2017) reports that to develop students' scientific attitudes, teachers can prepare interesting themes, the teacher provides a discovery / investigationbased learning experience both in the laboratory and in the environment. In comparison to what has been proposed by Gupta \& Pasrija (2016) that the teacher's role is very important to encourage students during the problem-solving process while taking risks in the process. The students' openness attitude can be developed during the selection of ideas, the process of group discussion, and the presentation of the product of investigation. The students are open to receive suggestions and criticism from group members and the members of other groups. The students' cooperation can be developed during the learning process. The students' scientific attitudes can be developed well with the implementation of the appropriate learning models. The results of this research show that the CITP learning model can develop students' scientific attitudes well. The same research results were also reported by Gautreau \& Binns (2012) that the scientific 
attitudes of the students taught by using the Inquiry learning model are better developed. Therefore, the syntax of the combination of the CITP learning model supports the scientific process, so that it can develop students' scientific attitudes. The results of this research are also supported by Zeiden \& Jayosi (2015) that the students will have a positive attitude towards science when they are interested and focus on proceeding in the science process.

\section{The Effect of Learning Models on Students' Cognitive Learning Results}

The results of the statistical test using the ANCOVA technique (Table 10) show that the combination of the CITP learning model affects students' cognitive learning results with a significant value of $<\alpha 0.05$. This indicates that the learning model affects students' cognitive learning results in several senior high schools in Ambon.

The results of the LSD test show that the cognitive learning results of the students taught by using the combination of the CITP learning model were not significantly different from those of the students taught by using the conventional learning model. However, the mean scores of the cognitive learning results of the students taught by using different learning models also show a difference (Table 11). Through the combination of the CITP learning model, the students were able to develop their cognitive learning results, so that they were different from the students taught by using the conventional learning model.

The students' learning success can be seen from the students' learning results. One of the learning results measured in this research was the students' cognitive learning results. The cognitive learning results in this research can be associated with the students' understanding of the ecosystem concepts taught using the CITP learning model. The students' conceptual understanding is formed through the learning process using the combination of the CITP learning model. According to Ramdiah \& Corebima (2014), the learning process is developed to influence students' thinking skills, which can then improve students' academic achievement. Through the learning process of selecting ideas, collecting information until conducting investigations in the field, making scientific products, and presenting the results of the investigation, the students learn to connect the concepts that have been studied with the results of the investigation. During the investigation process in various ecosystems, students can observe the components and interactions between components in the ecosystem. This process can shape students' cognition to understand ecosystem concepts. Nursyami \& Corebima (2016) added that so that students can understand the phenomena that occur in their environment, the learning must stimulate students to actively think through observation or experimentation and social interaction between students and teachers. Yuliati, Maridi, \& Masykuri (2018) report that when the students express ideas, answer hypotheses, and have a discussion in their learning process, they will understand the learning material better. Veselinovska (2011) added that students' biology learning results increased when the learning started with experiments compared to the lecturing method.

\section{The Effect of Learning Models on Students' Retention}


The results of the statistical test using the ANCOVA technique (Table 12) show that the combination of the CITP learning model affects students' retention with a significant value of $<\alpha 0.05$. This shows that the learning model has an effect on students' retention in several senior high schools in Ambon.

The results of the LSD test show that the retention of the students taught by using the combination of the CITP learning model was not significantly different from that of the students taught by using the conventional learning model. However, the mean scores of the retention of the students taught by using different learning models also show a difference (Table 13). Through the combination of the CITP learning model, the students can develop their retention, so that it is different from the students taught by using the conventional learning model.

The retention of the concept of an ecosystem is the ability to remember the concepts of the ecosystem after being taught. The good retention of the students will be able to support their academic success. The higher the students' retention is, the better the students' ability to store information well and retrieve it for the next activity (Wicaksono \& Corebima, 2015). Similarly, Rumahlatu \& Sangur (2019) state that students' retention will be stronger if students have meaningful learning experiences. The activities of the CITP learning process provide opportunities for students to empower their retention. These activities are the activity of conducting investigations and making scientific products for presentations. The scientific products are in the form of scientific reports, images or blueprints of ecosystems. When creating this scientific product, students must initially examine the theories or concepts related to ecosystems.

The interaction among the students either personally or socially, sharing responsibility, and group work can increase students' retention (Thomas, 2002; Crosling, 2017). Similarly, Cuseo (2011) also explains that better retention is influenced by the availability of clear information, communication among students, the opportunities to participate in decision making, and the availability of experience.

In the combination of CITP learning model in this research, the students are trained to work together and to communicate with each other to decide on ideas that will be used for investigation stage, to cooperate to play different roles to carry out tasks, to have direct experience of conducting investigations, and to cooperate to produce products and to communicate to present the products. The students in the control class who were taught by using the conventional learning model and learning method only had the experience of observing ecosystems, cooperation, and discussion, but they lacked the experience of expressing ideas, investigation process to solve problems, and producing scientific products in the form of work reports or other two-dimensional products. The research conducted by Achebe (2008) also shows that the retention of the students in the experimental class is better than that of the students in the control class.

\section{CONCLUSION}

Based on the results of the research, it can be concluded that the combination of the CITP learning model can improve students' creative thinking skills, critical thinking 
skills, metacognitive skills, scientific attitudes, cognitive learning results, and retention in several senior high schools in Ambon. The combination of the CITP learning model provides awareness for the students through the use of role cards, contextual experience to explore the ecosystem, then guides the students to create products in the form of creative works to be presented to the other groups in the class. Therefore, it is expected that biology teachers implement the combination of the CITP learning model to optimize the ecosystem environment observation activities and the creation of more creative learning products.

\section{ACKNOWLEDGMENTS}

The researcher expresses his gratitude to the Faculty of Teacher Training and Education, Pattimura University for providing research funds through the Social Research, Humanities and Education grant in the 2018 budget year with No SK. 955 / UN13 / SK / 2018 dated July 10, 2018.

\section{REFERENCES}

Achebe, A. E. (2008). Effect of videotape instructional package on achievement and retention in food and nutrition at senior secondary school level in Minna, Niger State. JOSTMED, 1(1), 33-39.

Al-Khayat, M. M. (2012). The levels of creative thinking and metacognitive thinking skills of intermediate school in Jordan: survey study. Canadian Social Sci., 8(4), 52-61.

Balaji, G. (2017). Role of science teacher in developing scientific attitude among secondary school students. Scholarly Res. J. for Interdisciplinary Stu, 4(37), 8413-8421.

Birgili, B. (2015). Creative and critical thinking skills in problem-based learning environments. Journal of Gifted Education and Creativity, 2(2), 71-80.

Borg, W. L \& Gall, M. D. (1983). Educational research, an introduction. New York: Longman.

Buku, M. N. I., Corebima, A. D., \& Rohman, F. (2016). The correlation between metacognitive skills and the critical thinking skills of the senior high school students in biology learning through the implementation of problem based learning (PBL) in Malang, Indonesia. Int. Journal of Academic Research and Development, 1(5), 58-63.

Bustami, Y., \& Corebima, A. D. (2017). The effect of JiRQA learning strategy on critical thinking skills of multiethnic students in higher education, Indonesia. Int. Journal of Humanities Social Sciences and Education (IJHSSE), 4(3), 13-22.

Candrasekaran, C. (2014). Developing scientific attitude, critical thinking and creative intelligence of higher secondary school biology students by applying synectics techniques. International Journal of Humanities and Social Science Invention, 3(6), 1-8.

Chomsiati, N. E., \& Baskoro, M. (2014). The development of biological learning model based integration jigsaw and discovery (save) to empower social interaction and learning outcome. Proceeding Biology Education Conference, 11(1), 957-962.

Coffman, D. M. (2013). Thinking about thinking: An exploration of preservice teachers' views about higher order thinking skills. University of Kansas. from 
https://kuscholarworks.ku.edu/bitstream/handle/1808/15086/

Coffman_ku_0099D_12928_DATA_1.pdf?sequen ce=1.

Corebima, A. D. (2009). Metacognitive skills measurement integrated in achievement test. Paper presented at COSMED, RECSAM, Penang, Malaysia.

Crosling, G. (2017). Student Retention in Higher Education, A Shared Issue. Encyclopedia of International Higher Education Systems and Institutions. (Online), (https://www.researchgate.net/publication/318133592_Student_Retention_in_Higher_E ducation_A_Shared_Issue),

Cuseo, J. (2011). Student retention: The big picture. Retrieved from https://www.se.edu/.../Student-Retention-The-Big-Picture.pdf.

Davies, D., Jindal-Snape, D., Collier, C., Digbya, R. Haya, P., \& Howea, A. (2013). Creative learning environments in education-A systematic literature review. Thinking Skills and Creativity, 8, 80-91.

Dimyati, M. (2018). Tantangan Riset di Era Disrupsi dan Globalisasi [Research challanges in the disruption and globalisation era]. National Seminar on Kesiapan Sumber Daya Manusia Indonesia di Era Disrupsi dan Globalisasi, Guest Lecture in Universitas Padjajaran. Retrieved from http://sdgcenter.unpad.ac.id.

Erol, E. Jager, A., Hold, P., Ott, K., \& Sihn, W. (2016). Tangible industry 4.0: A scenario-based approach to learning for the future of production. Pro. CIRP, 54, 13-18.

Facione, P. A. (2015). Critical thinking: What it is and why it counts. Insight Assessment, 1-28. Retrieved from https://www.insightassessment.com/Resources/Importance-of-Critical-Thinking/CriticalThinking-What-It-Is-and-Why-It-Counts.

Gautreau, B. T., \& Binns, I. C. (2012). Investigating student attitudes and achievements in an environmental place-based inquiry in secondary classrooms. International Journal of Environmental \& Science, 7(2), 167-195.

Gupta, M., \& Pasrija, P. (2016). Problem solving ability \& locality as the influential factors of academic achievement among high school students. Issues and Ideas in Education, 4(1), 37-50.

Hariyadi, S., Corebima, A. D., Zubaidah, S., \& Ibrohim. (2018). Contribution of mind mapping, summarizing, and questioning in the RQA learning model to genetic learning outcomes. Journal of Turkish Science Education, 15(1), 80-88.

Hasan, S., Tumbel, F. M., \& Corebima, A. D. (2013). Empowering critical thinking skills in Indonesia Archipelago: Study on elementary school students in Ternate. Journal of Modern Education Review, 3(11), 852-858.

Howard, L. W., Tang, T., \& Austin, M. J. (2015). Teaching critical thinking skills: Ability, motivation, intervention, and the Pygmalion effect. Journal of Business Ethics, 128(1), 133-147. 
Huda, M. (2013). Cooperative learning; Metode, teknik, struktur dan model penerapan [Cooperative Learning; Method, Technique, Structure, and Implementation of Model]. Yogyakarta: Pustaka Pelajar.

Jahangard, Z., Soltani, A., \& Alinejad, M. (2016). Exploring the relationship between metacognition and attitudes towards science of senior secondary students through a structural equation modeling analysis. J. of Baltic Science Education, 15(3), 340-349.

Kementerian Riset, Teknologi, Dan Pendidikan Tinggi Republik Indonesia. (2018). Pengembangan Iptek dan Pendidikan Tinggi di Era Revolusi Industri 4.0 [The Development of Science and Technology and Higher Educaiton of the Era of Industrial Revolution 4.0]. Retrieved 5 January, 2019 from https://www.ristekdikti.go.id/siaran-pers/pengembangan-iptek-dan-pendidikantinggi diera-revolusi-industri-4-0/.

Kopzhassarova, U., Akbayeva, G., Eskazinova, Z., Belgibayeva G., \& Tazhikeyeva, A. (2016). Enhancement of students' independent learning through their critical thinking skills development. Int. J of Environmental \& Science Education, 11(18), 11585-11592.

Kristiani, N., Susilo, H., Rohman, F., \& Corebima, A. D. (2015). The contribution of students' metacognitive skills and scientific attitude towards their academic achievements in biology learning implementing Thinking Empowerment by Questioning (TEQ) learning integrated with inquiry learning (TEQI). International Journal of Educational Policy Research and Review, 2(9),113-120.

Kusuma, E. D., Gunarhadi, G., \& Riyadi, R. (2018). The strategies to improve critical thinking skills through problem-based quantum learning model at primary school. Int. Journal of Multicultural and Multireligious Understanding (IJMMU), 5(4), 123-129.

Lai, E. R. (2011). Metacognition: A literature review. Retrieved from Pearson's research report series: http://images.pearsonassessments.com/images/tmrs/metacognition_literature_review_final.pdf.

Leen, C. C., Hong, H., Kwan, F. F. H., \& Ying, T. W. (2014). Creative and critical thinking in singapore schools. Singapore: National Institute of Education, Nanyang Technological University.

Listiana, L., Susilo, H., Suwono, H., \& Suarsini, E. (2016). Contributions from the GITTW (Group Investigation Combined Think Talk Write) Strategy. Proceeding of ICTTE FKIP UNS, 1(1), 411-418.

Mas'ud, Ahmad, A., \& Arsyad. N. (2018). The development of metacognitive skillsbased teaching materials. Journal of Education and Learning, 12(4), 731-738.

Mite, Y., \& Corebima, A. D. (2017). The correlation between critical thinking and the learning results of the senior high school students in biology learning implementing group investigation (GI) learning in Malang, Indonesia. Journal of Applied and Advanced Research, 2(2), 56-62.

Mukhopadhyay, R. (2014). Scientific attitude some psychometric considerations. Journal of Humanities and Social Science, 19(1), 97-100.

Mumford, M. D., Medeirod, K. E., \& Partlow, P. J. (2012). Creative thinking: Processes, Strategies, and Knowledge. Journal of Creative Behavior, 46(1), 30-47. 
Nursyamsi, S. Y., \& Corebima, A. D. (2016). The effect of numbered heads together (NHT) learning strategy on the retention of senior high school student in Muara Badak East Kalimantan, Indonesia. European Journal of Education Studies, 2(5), 47-58.

Rahimirad, M., \& Zare-ee, A. (2015). Metacognitive strategy instruction as a means to improve listening self-efficacy among Iranian undergraduate learners of English. International Journal of Instruction, 8(1), 117-132.

Ramankulov, S., Usembayeva, I., Berdia, D., Omarova, B., Baimukhanbetova, B., \& Shektibayeva, N. (2016). Formation of the creativity of students in the context of the education informatization. Int. J. of Environmental and Sci. Edu, 11(16), 9598-9613.

Ramdiah, A. \& Corebima, A. D. (2014). Learning strategy equalizing students' achievement, metacognitive, and critical thinking skills. American Journal of Educational Research, 2(8), 577-584.

Riyana, C. (2018). Tantangan Pendidikan di Era Revolusi Industri 4.0 [Educational Challenges in the Era of Industrial Revolution 4.0]. Presented on guest lecture on October 31st, 2018. (Online), (https://um.ac.id/content/page/2/2018/11/tantanganpendidikan-era-revolusi-industri-4-0).

Rumahlatu, D., \& Sangur, K. (2017). Implementation of project-based learning strategies to improve metacognitive skills and understanding of biodiversity concepts in state high school 2 Kairatu, West District of Seram. Proceeding The 2nd International Seminar on Education, 1(1), 43-48.

Rumahlatu, D., \& Sangur, K. (2019). The influence of project-based learning strategies on the metacognitive skills, concept understanding and retention of senior high school students. Journal of Education and Learning, 13(1),104-110.

Saglam, A. C., Cankaya, I., Ucer, H. \& Cetin, M. (2017). The effect of information literacy on teachers' critical thinking disposition. J. of Edu. and Learning, 6(3), 31-40.

Seferoglu, S. S., \& Akbıyık, C. (2006). Teaching critical thinking. Hacettepe University Journal of Education, 30, 193-200.

Sele, Y., Corebima, A. D., \& Indriwati, S. E. (2016). The analysis of the teaching habit effect based on conventional learning in empowering metacognitive skills and critical thinking skills of senior high school students in Malang, Indonesia. International Journal of Academic Research and Development, 1(5), 64-69.

Sharma, H. L., \& Nasa, G. (2014). Academic self-efficacy: A reliable predictor of educational performances. British Journal of Education, 2(3), 57-64.

Sompong, N. (2018). Learning management system for creative thinking skills development with collaborative learning of the graduate students in Kasetsart University. Int. Journal of Environmental \& Science Education, 13(6), 527-532.

Stephanou, G., \& Mpiontini, M. H. (2017). Metacognitive knowledge and metacognitive regulation in self-regulatory learning style, and in its effects on performance expectation and subsequent performance across diverse school subjects. Psychology, 8(12), 1941-1975. 
Thomas, L. (2002). Student retention in higher education: The role of institutional habitus. Journal Education Policy, 17(4), 423-442.

Treffinger, D. J., Young, G. C., Selby, E. C., \& Shepardson, C. (2002). Assessing creativity: A guide for educator. Center for creative learning. Florida: Sarasota.

Umam, K., Suswandari, Asiah, N., Wibowo, I. T., \& Rohim, S. (2017). The effect of think-pair-share cooperative learning model assisted with ICT on mathematical problem-solving ability among junior high school students. Workshop Proceedings of the 25th International Conference on Computers in Education (ICCE), New Zealand: Asia-Pacific Society for Computers in Education, 94-98.

Veselinovska, S. S. (2011). The effect of teaching methods on cognitive achievement, retention, and attitude among in biology studying. Cypriot J. of Edu. Sci., 4, 175-185.

Wicaksono, A. G. C., \& Corebima, A. D. 2015. Hubungan Antara Keterampilan Metakognitif Dan Retensi Siswa Dalam Strategi Pembelajaran Reciprocal Teaching Dipadu Jigsaw Dikelas X SMAN 7 Malang [The Relationship Between Metacognitive Skills and Student Retention in Jigsaw Combined Reciprocal Teaching Learning Strategies in Class X SMAN 7 Malang]. Bioma, 4(1), 58-68.

Yuliati, Maridi, \& Masykuri, M. (2018). The influence of biology learning using concept attainment model on student's cognitive learning achievement. Journal of Education and Learning, 12(4), 767-774.

Yusnaeni, Corebima, A. D., Susilo, H., \& Zubaidah, S. (2017). Creative thinking of low academic student undergoing search solve create and share learning integrated with metacognitive strategy. International Journal of Instruction, 10(2), 245-262.

Zeidan, A. H., \& Jayosi, M. R. (2015). Science process skills and attitudes toward science among palestinian secondary school students. World J. of Edu., 5(1),13-21.

Zimmerman, B. J. (2000). Self efficacy: An essential motive to learn. Contemporary Educational Psychology, 25(1), 82-91.

Zubaidah, Z., Fuad, N. M., Mahanal, S., \& Suarsini, E. (2017). Improving creative thinking skills of students through differentiated science inquiry integrated with mind map. Journal of Turkish Science Education, 14(4), 77-91.

Zubaidah, S., Corebima, A. D., Mahanal, S., \& Mistianah. (2018). Revealing the relationship between reading interest and critical thinking skills through remap GI and remap Jigsaw. International Journal of Instruction, 11(2), 41-56.

Zubaidah, S., Corebima, A. D., Mistianah. (2015). Asesmen Berpikir Kritis Terintegrasi Tes Essay [Integrated Critical Thinking Assessment Essay Test]. Symposium on Biology Education, 200-213. 